\title{
Urban Projects to Prefigure the Sustainable City -- Case: the City of Ain Beida (Algeria)
}

\author{
Foued Benghadbane*, Fatima Zohra Berkani
}

Institute of Urban Techniques Management, University of Oum El Bouaghi, Algeria

Copyright $\bigcirc 2017$ by authors, all rights reserved. Authors agree that this article remains permanently open access under the terms of the Creative Commons Attribution License 4.0 International License

\begin{abstract}
Algerian cities suffer from multiple problems, which directly had influence in blocking the realization of the sustainable urban development and made it a significant challenge faced by many studies and researches especially urban projects that have become the modern tools of urban planning and which take into consideration the sustainable urban development dimensions within its basic guidance. Field practice of urban planning has proven that theoretical studies and political strategies cannot achieve the required sustainability, because it needs to activate the principle of people's participation and partnership between different actors during planning required urban projects, without neglecting the leading role played by the decision-makers, and that needs more rationalization to achieve good urban governance, which is the primary objective of urban project. In this context, the aim of this study is to provide the mechanisms that help to create sustainable and locale made urban projects, compatible with the natural, cultural and social characteristics of the Algerian cities taking the city of Ain Beida in the Algerian east area to apply this study, by placing a comprehensive systematic approach that combines urban sustainability problems of the city with the proposed solutions, through urban projects to monitor the ambitions of the population in the planning of their city, which would promote the city of Ain Beida to the class of sustainable city with optimum and rational exploitation of technologies and the available sophisticated means, and to stop the import of ready-made Western solutions, which is the main reason for the today's Algerian cities problems.
\end{abstract}

Keywords Urban Project, Sustainable Urban Development, Participation, Good Governance, the City of Ain Beida, Algeria

\section{Introduction}

The study of urban sustainability is of particular importance in recent decades. This is due to the inability of many countries of the world to meet the objectives of the sustainability concept, particularly the cities of Arabic countries that are suffering from many urban problems today. This situation is due to the lack of social justice and unequal distribution of wealth among the population. In addition, the environmental problems, resulting from economic activities and urban practices have led to the deterioration of the quality urban life [1]. Therefore, some states have adopted the $21^{\text {st }}$ local note contained in the chart of Aalborg, which is made in order to bind the various actors, which intervene in the urban system, and with consulting civil society managers, the local elected officials, residents, local associations, and non-governmental and economic institutions [2]. This approach requires the activation of good governance.

In order to meet the objectives of the note 21 , most cities in the world have become real workshops to achieve their ambitions and to fulfill the requirements of sustainable cities that respect the principles of sustainable development and to keep pace with social, economic, environmental and cultural challenges of urbanization for the welfare of the population [3].

The situation is not different in the Algerian cities that are threatened and wrapped by the complex urban problems which affect the economic and social well-being of residents and threaten the surrounding environment. These problems are resulted primarily from the applied urban planning methods since the independence (1962), which were far away from the concerns of residents and characteristics of the local communities, which are supposed to be the center of interest of all urban interventions.

Since the spatial and economic independence, the Algerian city in general and the city of Ain Beida in particular, are witnessing social and cultural shifts, as result of industrialization policy, and the phenomenon of rural flight. This development strategy has led to a deep impact on the rhythm of urban growth and inflation of cities sizes and the emergence of urban problems. The deterioration of urban conditions is caused by the main interest in the quantitative aspect rather than the qualitative side of urban production. All the attention was focused on the growing demand for 
housing in order to absorb the serious shortage in this sector neglecting other functional spaces that were supposed to accompany these communities.

That has a negative impact on the urban image of the Algerian cities, as the field of crystallization of all the political, economic and cultural changes, and mirror reflective of the decisions taken by the State in all fields. The decentralization policy especially in urban domain has resulted to developing tools, which was expected to solve the problems suffered by the Algerian city in the post-independence period. However, it actually increased the complexity because of the negatives that accompanied these tools, which produced incoherent and marginalized urban areas that cannot meet the inhabitants' requirements which led to the failure of the central linear policy. And at the same time, it confirmed the need to look for solutions that care for further quality as well as quantity at the intervention in the city and encouraged the adoption of a strategic planning that takes into account all the urban dimensions when proposing any project. In addition, it also met the needs of the residents of the city in all fields to achieve a balance among social, economic, environmental and cultural challenges of urbanism and to transform quantitative urban growth of Algerian cities to urban sustainable development.

In the beginning of the new millennium, the Algerian state took a new turning point in the field of planning and management of urban areas, in order to reduce the severity of the problems of our cities and rectify the deficiencies produced by the past urban policies. These policies have been translated into practice by the planning and urbanization tools of Master Plan and Land-use plan. These tools are characterized by the length of achievement periods compared with the rapid urban growth, making them lose their efficiency to respond to the objectives assigned to them.

The economy market contributes to the adoption of spatial planning instead of central and sectoral planning, and drives the state to think of new approaches to keep pace with local and global changes. This trend represents the foundation of a city's policy that depends on the achievement of sustainable development in the urban area and build a strong urban economy, especially in light of the availability of capital and prosperity of the national economy as a result of high petrol prices, and the Law of sustainable development of the region $\mathrm{n}^{\circ}$ 01-20 dated 12.12.2001 which works to confirm the objectives of the planning and urbanization law in the context of sustainable development as a framework for an integrated multilateral dimensions and sectors, under which the city has become an important place within this new policy of urban planning.

The State also confirmed the new orientation in urbanism field and management of the cities in the context of urban project by issuing a guideline law of the city $n^{\circ} 06-06$ dated 20.02.2006 and accompanying tools, as a new urban approach referred to the socio-economic and spatial development of the city. A sustainable development in time and space is based implicitly on the principles of urban project of an Upgrade of social cohesion and integration of all the actors in the production and management of the urban area, to ensure the terms of the prosperity of the cities, protect the environment and promote partnership and cooperation between cities. Despite the importance of this law, it is not executed and translated in reality; though it has been released 10 year ago. This is what held it in the theoretical framework, and make urban project just a theory ideas. At the moment the tool that is trying to achieve the city's policy in Algeria is the urban coherence plan (SCU)issued by the Ministry of the reorganization of the region and sustainable development, which emerged by some urban projects that seem as if it doesn't coincide with the fashionable concept, which had not gotten legislative right in Algeria yet.

\section{Methodology}

The Search adopted to achieve the objectives on the theoretical sources represented in books, articles and scientific references directly related to the subject, in addition to the general censuses of population and housing issued by the National Office of Statistics. Data related to social, economic, urban, and environmental dimensions, are derived from the field work. They rely on questionnaire to collect data on population, activities and the characteristics of urban surroundings (roads and various networks, and green spaces ...) as well as the distribution of service equipment.

The Search adopted a systemic approach which is based on the logic of causality and correlation effects in the systems that are centered on the study and of economic, environmental, urban, social and cultural system and other systems urban area.

\section{The Importance of Situational, Demographic and Urban Growing of Ain Beida City}

The city of Ain Beida is the most important city in the east of Algerian in terms of population size (115 286 people, according to the General Census of Population and Housing for the year 2008), the impact of urban policies, its history, capabilities, components and its problems. It represents a real sample of the Algerian city that suffers from mixed and multiple problems within the content of social and economic potential of the environment that allows them to incorporate the sustainable urban development.

The city of Ain Beida, with $20 \%$ of the population of the Wilaya of Oum El Bouaghi, is one of the main cities representing the municipalities (621 612 people in 2008), and that's what makes it characterized by a density estimated at 2045 inhabitants $/ \mathrm{km}^{2}$ which is very high compared with other cities in the wilaya. These features make the city have the priority in receiving programs and projects that are 
seeking the advancement of the local economy and guide the growth path towards urban sustainability. In addition to this, the city of Ain Beida occupies an important geographic location, where it mediates the territory of the wilaya and the territory of the eastern high plateau. The city is crossed by two axes the National Road $n^{\circ} 10$, which connects wilaya of Constantine and wilaya of Tebessa, and the National Road $n^{\circ}$ 80 , which connects wilaya of Guelma and wilaya of Khenchela. This geographic situation makes it a strategic crossing between the cities of the Middle Algerian point (Map 1).

The natural, urban and architectural properties and cultural legacy make the city a particular attraction. It's considered as an important commercial and administrative centering the wilaya because of the important grid of roads that make up the knot to various national roads in different directions. In addition to that, the industrial zone allows the city to play a leading role in the territory of the wilaya. Proceeding from this role, the city, since the post-independence period, has witnessed sharp exodus rural and quickly urban evolution. The creation of planned avenues like "Marianne", shanty town like "Al kariyar", and solid anarchist housing lead to accelerate pace urban growth, due to the high demand for housing and associated equipment [4]. The lack of planning leads to irrational consumption of urban and agricultural land through emergency housing operations. This has resulted to unplanned and random development and creating several problems affecting the urban quality of life. The deterioration of urban conditions prevents the upgrading of the city and makes it difficult to convert it to sustainable city that meets social, economic and environmental requirements of current and future residents.

The city of Ain Beida suffers from multi-faceted urban crisis, mainly the lack of necessary urban land for the city extension. This is due to the nature of urban surroundings that prevent the spatial evolution of the city. The administrative municipality border that is the urbanization circumference presents private land sector and forestland, railway and power grid. The land constraint necessitates the need to go back into the city to find solutions to the urban problems. However, in the presence of privately owned urban enclaves, the city cannot take advantage of them after the acquisition by the municipality [5].

The increase of the incomes of petroleum since 2005 made Algeria witness some kind of financial easiness. Algeria tended to planning special major projects including basic structures, to keep pace with globalization, which came with the principle of sustainable development. This translates to the emergence of several major and important urban projects in quantity and quality, working primarily on the growth of urban tissue and improvement of living conditions of the population through engaging them in the production and management of their urban field.

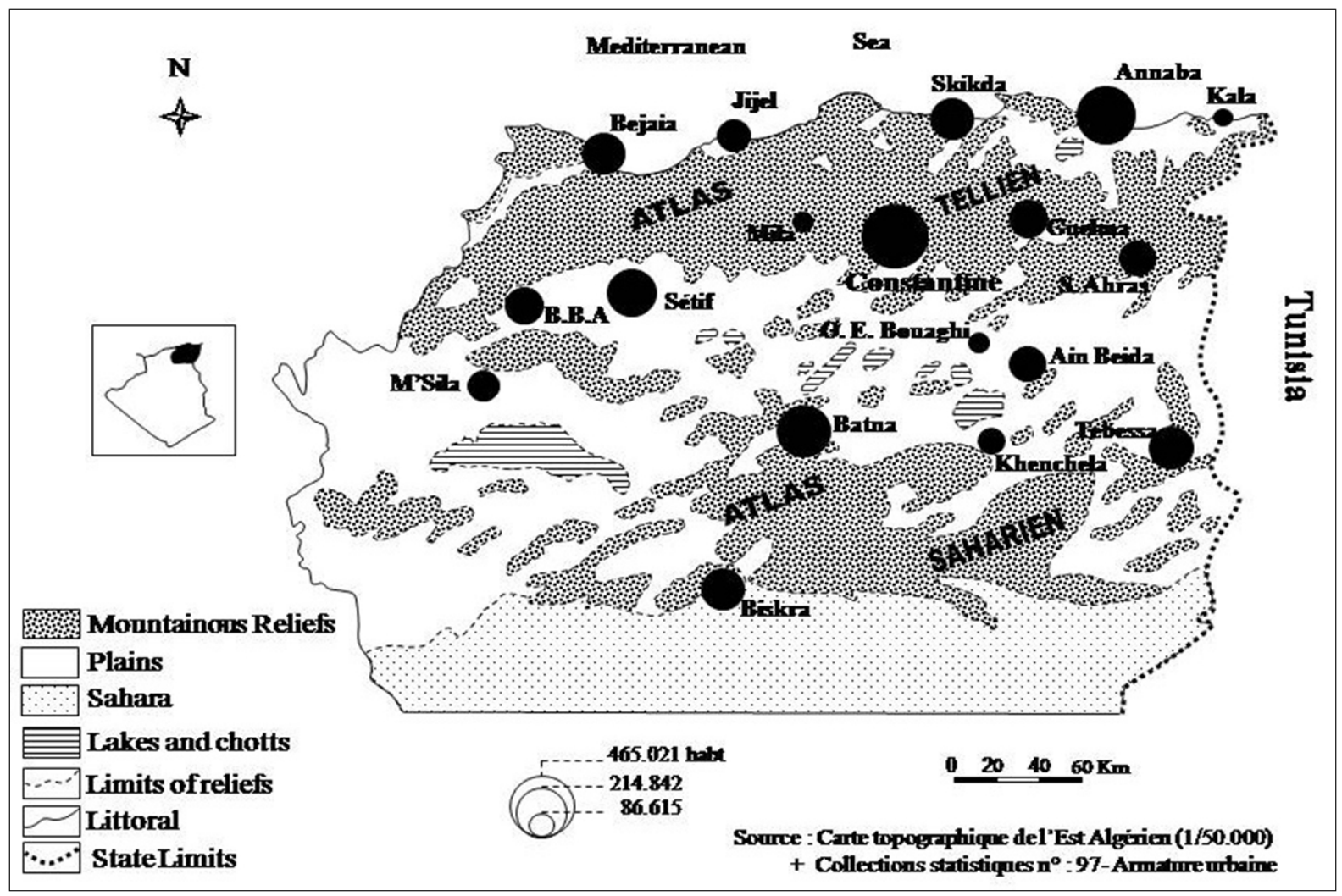

Map 1. Geographic Situation of Ain Beida city 


\section{An Important Place for the City of Ain Beida within the Urban Planning System}

After Algeria ratification of international treaties relating to the necessity to integrate sustainable development in the various strategies of planning, the state issued a guideline law of the city No. 06-06 dated February 20, 2006 and which has worked renewal of legal and legislative arsenal relating to urbanism, in order to put the city in the heart of urban policies by a new instrument of urban planning. Planned urban coherence and that is appropriate for the process of sustainable urban development, which can be exercised from two perspectives: the protection of natural resources and protection from risks. Drawing on the city scale to intervene and try to address the problems of the cities that exceed the size of 100,000 people, which is consistent with the reality of the city of Ain Beida. The city has benefited from the scheme of urban coherence in 2008 in order to try to address urban problems (Map 2).

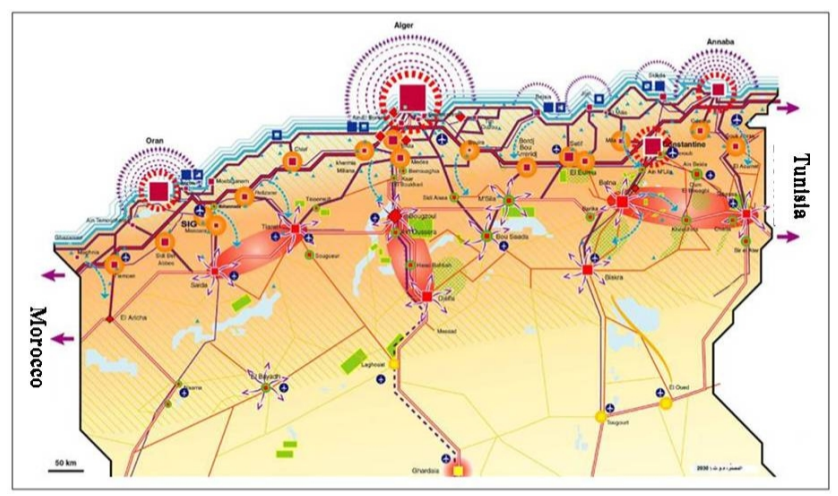

Map 2. Place for the city of Ain Beida with in the urban planning system.

The urban coherence scheme of Ain Beida was prepared by the Studies office CENEAP under the supervision of the Environment Directorate of the wilaya of Oum El Bouaghi. It aims primarily to achieve sustainable development of local urban in the city of Ain Beida, as an instrument to embody the principles of sustainable development on the city scale during the conditions ensuring respect for the basic principles of sustainable development that are stated as the following:

- The principle of balance in achieving sustainable development goals: by working to achieve a balance between urban and rural development, the protection and exploitation of agricultural and forest land and the protection of the landscapes and sensitive ecosystems.

- The principle of diversity in urban activities and social integration: the balance between the patterns of urban land by avoiding the creation of only activity areas, except in case of necessity, and working on mergers between different types of housing in the same area.

- The principle of respect for the environment: Through the exploitation of rare area and the protection of natural and architectural heritage. Taking the various natural and human types of risks into account while addressing areas.

As stated in urban coherence scheme, the master plan of Ain Beida is to try to address the problems and preoccupations in the context of the municipal areas. The urban coherence scheme (UCS) tends to apply a strategy for the local sustainable development. Town planners try to control the local dynamics of Ain Beida city, to ensure the two-dimensional integrated development:

- The Strategic dimension guaranteed by the urban coherence scheme.

- The legal dimension determines the conditions of land use guaranteed by Master Plan for the creation of reconstruction and development and the patterns of fill the land associated with it.

The urban coherence scheme represents a new instrument in the planning system. The fundamental mission is to eliminate the imbalances plague of the city in the perspective of harmonization and coherence between the city's configuration and development programs in the urbanization field, housing, economic and social development, transportation, the environment and the risks threatening the city. In order to achieve these goals, the urban coherence schemes decide that planning processes must not be confined to the urban context of the city, but must deal with the neighboring region which is a basin of daily life for the inhabitants. The scale of intervention covered by the urban coherence scheme is the urban area, because it is the most appropriate scale to achieving urban sustainable development

\section{Features Urban Sustainability and Axial Position of Urban Project in the Strategic Planning for the City of Ain Beida}

The urban coherence scheme is a strategic instrument for the local and regional development of the city. The aim is to achieve a balance between resource management and justice in the distribution of local wealth owned by the city of Ain Beida, which is expensive to play an essential role in the participatory approach to the development of the regional area of the city of Ain Beida.

The scheme considered the city of Ain Beida as a structured pole and an attractive and competitive center at the state level. It is a policy shared among the various actors interested in the development of the city of Ain Beida. The plan is a strategic planning and practical instrument for evaluation and follow-up. It is an instrument to get real knowledge of the territory and the embodiment of dialogue and consultation among the various actors on the strategic directions of the urban area. 
It also seems that the spatial imbalances of the city of Ain Beida lie in the phenomenon of urban expansion experienced by the city despite the limited area. This phenomenon has led to many problems, especially those related to traffic. The urban coherence scheme of the city tries to find an alternative to this irrational urban growth which is confined to the renovations. They concern about the colonial core and aim to the valuation of the urban heritage in the city, on the one hand, and go about the policy of city building on the city or return to the city on the other hand

The main objective of the urban coherence scheme of the city of Ain Beida is to support gravity and competitiveness exercised by the city of Ain Beida on the level of the territory of the state. This could be achieved through the valuation of the urban and the natural and cultural heritage of the city, in order to change the scale of the gravity from the local to the regional level, by identifying size and location of major equipment and basic functions to be annexed by the city of Ain Beida in the next twenty years. This needs table for monitoring, and follow-up and assessment, which determines a clear and tidy manner for the most important priorities that concerning for the city of Ain Beida during a certain period of time.

The practice of bilateral "follow-up - Evaluation" consists of two different date ranges, the first date during the data collection using performance indicators during the achievement of the project, and the second one during the analysis of activities and effects by using indicators of success which refers to the extent to which the objectives of the project after the completion of it. This means that these indicators are tools to evaluate various aspects of the project or program. In case of careful construction of these indicators, it will allow decision-makers of urban domain to follow up progress of the projects, and take appropriate action, which will allow improving the quality of implementation of urban projects. To achieve these objectives, it has identified urban coherence scheme for the city of Ain Beida five key points, namely:

- Geographical and physical supervision of urban area: which ended at identifying two scales of intervention on the urban area, namely: urban scale that represents the area that extends the city offline or area of life, and regional scale for the city allocated for future growth of the city (the expansion of city in the medium and long term).

- Strategic diagnosis of urban area of the city of Ain Beida: necessary in order to understand the area of intervention, which targets the following strategic topics:

- Social and urban development.

- Economic urban development.

- Basal structures.

- Urban Governance.

This strategic diagnosis has concluded that the city of Ain Beida is a multi-faceted city. They are residential city primarily which has diverse housing styles, and has at the same time quite a number of economic and social activities and basal equipments.

- Development Strategy: This strategy boils down to four key themes, namely:

- Housing and Urbanism: The need to maintain the diversity is a characteristic of the city. It is a positive factor to increase the attractiveness of the city at the local and regional level. The first objective is to achieve a balance between the patterns of land use and support the dominance of the city center role. The second objective is to create centers of neighborhoods and to reduce urban interruptions beside the rehabilitation of neighborhoods in major urban agglomerations.

- Economic development: The target is to provide appropriate conditions for the economic institutions that will contribute to the elimination of the unemployment, which seems to be the major constraint of the city. These institutions must take into account the social and professional composition of the population in order to accompany the economic development of the city with social development and improved living standards of population.

- Environment: Urban coherence scheme takes into account the environmental dimension. This is a new addition that differentiates the scheme from the master plan of the city. In this context, the scheme confirms the need to protect all types of vegetation in the city, to upgrade the urban appearance and to protect the urban and natural heritage. The objective is to consider the dimension of sustainable development in the future urban projects, especially in the field of water management, encouraging the use of renewable energies and the protection from natural hazards.

- Equipments, public spaces, transport and mobility: by working to provide the appropriate conditions for endemicity of the equipments with regional _radiation, reformat the existing public squares and create new ones, and to support the diversity of modes of transport and to upgrade the quality of service.

- Urban configuration strategy: It is summarized in the detailed plans for the intervention and corresponds with the four axes of development strategy as follows:

- Housing and Urbanism: The scheme emphasizes the need to limit the phenomenon of urban expansion, the classification of the city center as a sector to be protected, the restructuring of the urban area of the city, and support the diversity of housing, the restructuring of neighborhoods in the suburbs and valuing the city entrances. 
- Economic Development: revitalize the city of Ain Beida Industrial Zone, with the valuing and development of the local road network, improving the quality of mass transit and support for all economic activities, especially commercial ones.

- Environment: In this field, the scheme axis the need to protect the natural and forest area, then the creation of a green belt surrounding the city of Ain Beida, the protection and development of the surrounding agricultural areas, and the protection of surface and underground water network. Together with effective management of the network of drinking water distribution and waste water drainage network, control the household solid waste management, and try to adapt to the risks of floods that threaten the city,

- Scale urban monitoring: This table consists of nine indicators of development and allows the systematic comparison of the extent of the embodiment of the city's policy and its effectiveness in the context of follow-up and evaluation brought by the urban coherence scheme to the city of Ain Beida.

These indicators are: the occupancy rate housing ORH, the occupancy rate of the room ORR, density of population, green spaces, the rate of linking the various networks, the rate of supervision, the rate of connectivity technologies, information and communication, and the coefficient of fill the land CFL coefficient seizure CS.

Accordingly, the urban coherence scheme is a tool for design and the embodiment of a practical urban multi-sectored planning. It works to guide the evolution of region in a sustainable development perspective, and in the framework of a project to create local sustainable development. The practical urban project that respects the principles and objectives of sustainable development is translated into a fact in the form of interventions in chronological order according to priority.

It also calls for respect for the principles and objectives of sustainable development during the programming and the implementation of all urban projects that belong to the city of Ain Beida, and stressed the principle of follow-up and evaluation of these projects, which stresses the need to create sustainable urban projects, but it is not an open and direct manner.

\section{Continuity Sectorial and Linear Planning after the Adoption of Urban Project in the City of Ain Beida}

Many of the regional urban projects have been done in Ain Beida, which were not included inmost of the urban planning of the city of Ain Beida. They are imposed by the necessity of development of the city, and therefore they are urban projects but without formal strategic framework, and represented in:

- Relation to the environmental dimension: it aims to minimize the environmental footprint, such as water purification plant, throwing urban waste center projects.

- Relation to the social dimension such as the university pole (Fig. 1), and amusement park.

- Of an economic dimension: such as the railway project (Fig. 2), and the expansion of the industrial zone projects (Fig. 3).

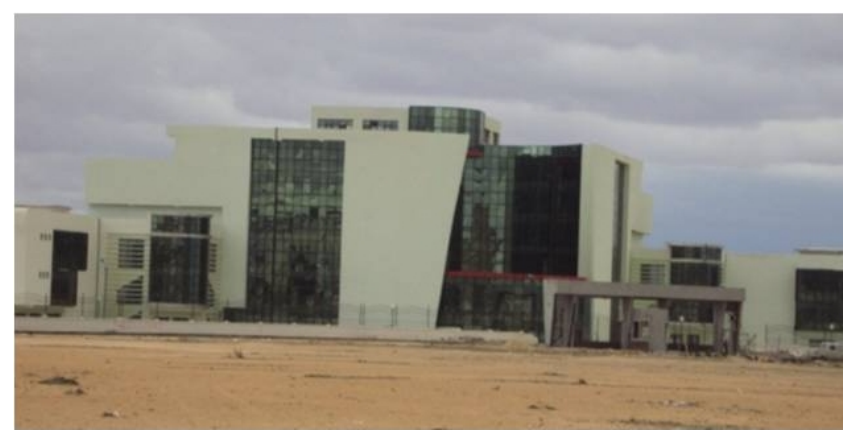

Figure 1. The university pole

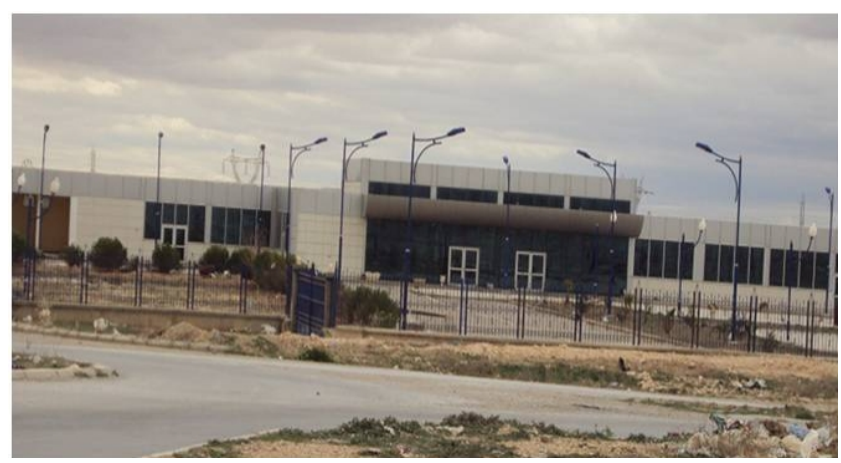

Figure 2. The railway project

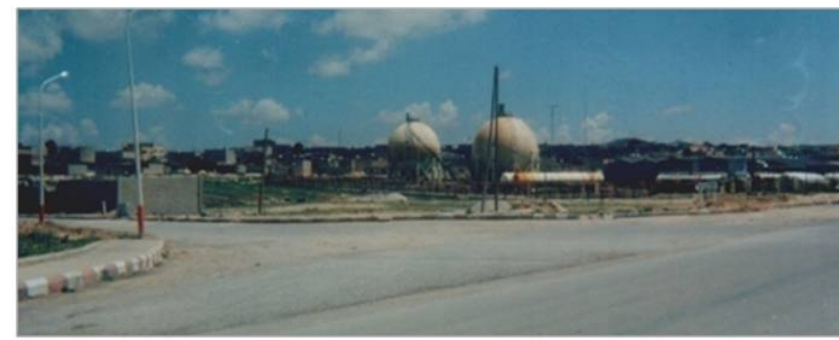

Figure 3. The expansion of the industrial zone projects

Urban Projects known in the city of Ain Beida, in the recent years, serve the environmental, social and economic dimension of the city of Ain Beida. They suffer from the absence of a comprehensive strategy between these projects, and make them sustainable urban projects working on direct urban growth of the city of Ain Beida to sustainable urban development. Because the absence of this kind of systemic approaches, it makes these projects ineffective, and has no effect on the framework of quality of life of residents.

In addition to that, these projects do not respect the main 
principle of urban project, a return to their construction within the city, because it is dedicated to urban expansion. Although some of them(such as the amusement park) could have been a great location within the urban tissue of the city of Ain Beida, but the absence of the principle of consultation and participation of different actors especially civil society makes these projects far from the reality of life of the population. Because the objective of urban project is the restoration of the link between the place and its surroundings and make the city more functional, or it is trying to improve the quality of urban life. These goals are achieved through the integration of the various actors in the urban production and create coherence and the abolition of sectorial plans. The main interest is to reduce the problems caused by rapid urban area evolution, and this is what pushes us to ask for the opinion of the population of the city of Ain Beida in these projects and in the reality of urban sustainability for the city of Ain Beida.

\section{Urban Project Perception and Experience the Urban Sustainability in the City of Ain Beida}

In order to identify the extent of urban project perception by the population, and identify problems that impede sustainable urban development in the city of Ain Beida and adjust their causes, it was necessary to do a questionnaire field that covers the research community.

The sample is represented by 22.162 families the scale which limits this society is the measure of permanent or temporary residence in the city of Ain Beida. The sampling method has been the Operations Group, which allows selection of a representative sample for the research community, which is estimated at $10 \%$ of the total households in the city of Ain Beida. A deliberate sample, while the preview mode and type were the probability previewing that the number of elements of the research community is known, and the objective is to disseminate the results to each research of the community.

The questionnaire results showed that the view of population towards urban projects and the nature of sustainability are divided into two teams. The first one comprises $62,60 \%$ of the population who see it as a good project and allows the improvement of the quality of life in the city because they contribute to local development to the city of Ain Beida and is working to relieve pressure on the city of Oum El Bouaghi (the wilaya capital). Also they think that despite its importance it came too late. The second team comprises $15,25 \%$ of the population and thinks that these projects have no effect on quality of life of the population. 22 , $15 \%$ of the population believes that decision makers have to consult the population before they accomplish such projects. It would interest them larger (Fig. 4), because the priority of the equipment and basic services such as housing and industrial projects that reduce the unemployment crisis and leisure projects support the tourist side of the city. In addition to that, these projects are not well thought out in a good way and not based on a realistic urban planning because their location are not appropriate and do not have any benefit because they did not move any dweller. For example the railway project, which is one of the expensive projects in which large sums of money has been wasted. If this investment is used in other projects, it would have more benefit. Some of the people demonstrate the failure of these projects that they have no ideas about these projects although they live in the city of Ain Beida [6].

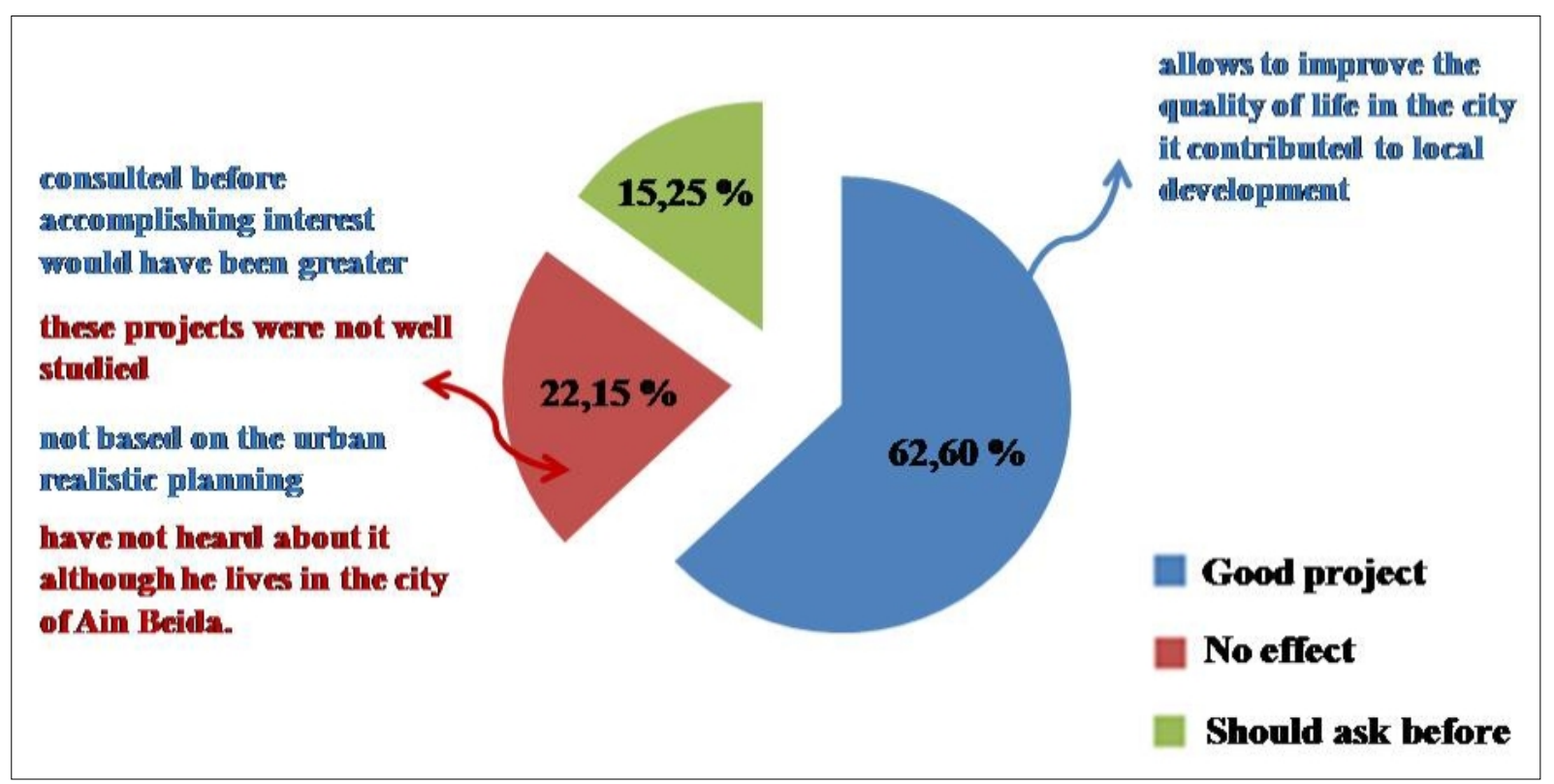

Figure 4. The population opinion in the Ain Beida city. 
This confirms that the urban project strategy is the optimal solution to the problems of sustainability in the city of Ain Beida. This type of intervention depends on two fundamental principles. Firstly, it deals with each area on the basis that it is unique in the properties, and therefore it has its own problems and seeks for specific solutions.

Secondly, it is working to absorb and translate the ambitions and aspirations of the population in the form of an urban concrete projects.

In addition to the study of the urban sustainability problems of the city of Ain Beida assures us that all the problems connected with each other, and this confirms that the systemic approach which is characterized by urban project sustainable is the optimal strategy that can promote the rate of sustainable urban development in the city of Ain Beida .

\section{The Proposal of a 21 Local Note Embodiment of Sustainable Urban Project in Ain Beida}

Ain Beida city needs to prepare a 21 local note that focuses on the systematic approach that combines the objectives of sustainable urbanization and sustainable urban project dimensions. The note may enable local groups, represented by the municipality at the level of the city of Ain Beida, to the application of good or sound practices. But despite of its importance, it cannot replace the political strategy of sustainable development, which is the regional reorganization planning, which in turn requires the activation and not being held in the theoretical framework.

The nature of good practices that should be annexed in 21 local notes varies from one area to another. Some of these practices were known before, and are reflected in one way or another. Other practices are new so they require the population awareness and being training by the executive bodies. The basic themes that revolve around these practices needed in the city of Ain Beida are as follows:

- Adjust the urban planning system of the city Ain Beida, in a way that the regional plans do not conflict with the urban plans, and enhance the relationship between the master plan for planning and urbanization and urban coherence planning.

- Develop an effective awareness program that includes all the population no matter what their age or social level, because the absence of awareness makes any solution not feasible and not effective.

- Reinforce the economic attractiveness of the city in order to create competitiveness between the most important neighboring cities.

- Improve the local environment quality

- Improve Sustainable management of the city.

- Enhance the natural and human resources of the city.

This is a good practice, in case of the correct application, that can transform the City of Ain Beida into a self-sufficient city and enables it to meet local needs of the population in all sectors. Active population and the economic activities contribute constantly to improving the living environment. A homogenous city ensures the spatial and socio-economic and environmental homogeneity among various urban activities in order to correct spatial imbalances. This may convert it into a sustainable city to ensure prosperity for all and create a capable and responsible society.

\section{Conclusions}

The urban projects that have been implemented in the city of Ain Beida in recent years are projects with huge budgets. However, they do not affect the quality of life of the residents in Ain Beida. Such as the railway project, as confirmed by many of the population, that is waste of money which could be allocated to real economic projects that have the ability to absorb the unemployment crisis in the city. These projects suffer from the absence of a comprehensive strategy. They tend to be sectorial projects that only fulfill one dimension of sustainable development. This is what makes them ineffective and have no effect on the quality of life of residents of Ain Beida.

The failure of these projects and the multiplicity of urban sustainability problems is explained by the absence of the principle of consultation and participation of different actors, especially civil society. In addition, they do not take into account the local characteristics of the city of Ain Beida. This confirms that the urban project strategy is the perfect solution to the problems of urban sustainability in the city of Ain Beida. Because this type of intervention is based on two fundamental principles, the first one deals with every area that it is unique in the properties, and therefore the problems and their solutions. The second one works to absorb and translate the ambitions and aspirations of the population in form of urban projects.

In addition to the study of urban sustainability problems of the city of Ain Beida, this assures us that they are interlinked. This confirms the inevitability of the overall vision and systemic approach that characterize the sustainable urban project. The optimal strategy can promote the sustainable urban development in the city of Ain Beida and elevate the city to the ranks of sustainable cities.

\section{REFERENCES}

[1] BEREZOWSKA-AZZAG Ewa, (2011), Projet urbain: guide méthodologique - connaitre le contexte de développement durable, collection urbanisme, Synergie, Alger.

[2] BELMER Jean, (2011), Pour un urbanisme de projet, de l'aménagement au renouvellement urbain, ellipses, Paris.

[3] CHARlot-VALDieU Catherine et autres, (2011), 
L'urbanisme durable: concevoir un écoquartier, Le moniteur, $2^{\text {eme }}$ édition, Paris.

[4] BENDADDA Toufik, (2007), Etude d'un quartier périphérique: cas de la cité Salem Ain Beida, mémoire de magistère, Université d'Oum El-Bouaghi, Algérie.

[5] BOUCHEMAL Saleh, (2009), Mutations socio spatiales en milieu urbain: entre citadinitéet ruralité, l'exemple d'une ancienne ville coloniale française en Algérie, inCahiers de géographie du Québec, Volume 53, n 149.

[6] BERKANI Fatima Zohra, (2014), Le rôle du projet urbain dans la durabilité des villes algériennes, cas de la ville d'Ain Beida, Mémoire de Magister en urbanisme, université d'Oum El Bouaghi, Algérie. 